\title{
The politics of negotiation and implementation: a reciprocal water access agreement in the Himalayan foothills, India
}

\author{
$\underline{\text { Eszter K. Kovacs }}^{1}$, Chetan Kumar $^{2}{ }^{2}$ Chetan Agarwal $^{3}, \underline{\text { William M. Adams }}^{1}$, Robert A. Hope ${ }^{4}$ and Bhaskar Vira $^{1,5}$
}

\begin{abstract}
In this paper, we examine the on-the-ground realities of upstream-downstream negotiations and transactions over ecosystem services. We explore the engagement, negotiation, implementation, and postimplementation phases of a "reciprocal water access" (RWA) agreement between village communities and municipal water users at Palampur, Himachal Pradesh, India. We aim to highlight how external actors drove the payments for ecosystem services agenda through a series of facilitation and research engagements, which were pivotal to the RWA's adoption, and how the agreement fared once external agents withdrew. In the postimplementation period, the RWA agreement continues to be upheld by upstream communities amidst evolving, competing land-use changes and claims. The introduction of cash payments for environmental services for forest-water relationships has given rise to multifaceted difficulties for the upstream hamlets, which has impeded the functionality of their forest management committee. Upstream communities' formal rights and abilities to control and manage their resources are dynamic and need strengthening and assurance; these developments result in fluctuating transaction and opportunity costs not originally envisaged by the RWA agreement. The paper demonstrates the importance of an explicit understanding of the local politics of negotiation and implementation to determine the effectiveness of compensationbased mechanisms for the supply of ecosystem services.
\end{abstract}

Key Words: India; negotiations; payments for ecosystem services; water management

\section{INTRODUCTION}

Payments for ecosystem services (PES) are instruments to recognize, protect, and manage the benefits humans derive from natural ecosystems and to maintain or enhance these flows (Engel et al. 2008, McElwee 2012). PES rewards individuals or communities whose land-use decisions have a positive impact on the supply of sought and well-defined services through a voluntary and conditional transaction between supplier and buyer (Wunder 2005). Such 'ideal-type' PES schemes encourage a particular focus on measurement, monitoring, and the conditionality of payments, and schemes with these elements have been proposed or adopted for the delivery of water and carbon sequestration (Porras et al. 2008, Wunder et al. 2008, Farley et al. 2013). However, incentivizing particular land-use and landmanagement strategies may give rise to new types of trade-offs because altering socio-environmental interactions directly affects local resource users, potentially exacerbating the vulnerability of some members of the community (Kerr et al. 2007, GoldmanBenner et al. 2012, Vira et al. 2012). Designing and implementing PES schemes that avoid these trade-offs and deliver both environmental protection and poverty alleviation requires a thorough and grounded understanding of local resource users and their aspirations and needs (Kerr 2002, Pagiola et al. 2005, Daw et al. 2011).

Watershed protection has a distinct up- and downstream geography whereby upstream activities such as herding or logging are assumed to affect the quality and quantity of water available further downstream (Calder 2005, Martinez et al. 2013). These geophysical relationships mirror and replicate, at the local scale, the previously popular "theory" of Himalayan environmental degradation, where upland cultivators and land users were blamed for lowland sedimentation, flooding, or water shortages (see Forsyth 1996, Guthman 1997, Blaikie and Muldavin 2004). This builds on much earlier discourses and beliefs about the potential links between land management practices in the Himalayas, and their consequential impacts on soil and water management regimes in the plains, dating back to the early colonial period. Saberwal (1999) for instance documents the changing rationale for restrictions on grazing in the Kullu and Kangra forest settlements in Himachal Pradesh, and their justification as measures for hydrological control and to address soil erosion. There are a number of examples of what would now be called an "ecosystem service" rationale being adopted for watershed management in different parts of the Indian subcontinent since the early 19 th century (Vira et al. 2012).

As subsequent work has shown, the protection of entire watersheds requires interventions in complex social-ecological systems, with users of different socioeconomic means and extensive land practices that result in highly variable costs and opportunities across stakeholders. These give rise to difficult-tomanage or predict "intangible" outcomes (Kerr 2007, Kosoy et al. 2007). The dynamics of landscape and forest management and their variable impacts on geo-hydrological processes (Bruijnzeel 2004), as well as the complex interactions within communities and between upstream and downstream actors (Kerr et al. 2014), require adaptive watershed management strategies that respond to changing knowledge and local political developments (Bonell and Bruijnzeel 2005). India has (at least from the 1970s) trialed and implemented a number of compensation schemes that recognize these upstream-downstream relationships in the context of watershed protection through World Bank-, NGO-, government-, and user-led incentive strategies (Kerr 2002, 2007, Kerr et al. 2007). Key insights from these projects include the importance of the conditionality of payments made contingent

${ }^{1}$ Department of Geography, University of Cambridge, UK, ${ }^{2}$ Global Forest and Climate Change Program, IUCN, Washington, D.C., USA, ${ }^{3}$ Center for Ecology Development and Research, India, ${ }^{4}$ School of Geography and Environment and Smith School of Enterprise and the Environment, Oxford University, UK, ${ }^{5}$ University of Cambridge Conservation Research Institute (UCCRI) 
on community performance, legal support, and clarity of property rights (Kerr et al. 2007).

In parallel, India has undertaken decades of decentralization for the formalization of existing community management of resources, particularly over forests (Agrawal 2001, Nayak and Berkes 2008). PES instruments are now receiving increased focus in the forest context, particularly in light of the 73rd constitutional amendment assigning devolved powers and functions to local government levels (Kerr 2002, Vira et al. 2012). This paper outlines one of the first PES-like agreements negotiated at Palampur town in the state of Himachal Pradesh. The state government has been in the vanguard of India's provinces in adopting the ecosystem services paradigm, and adopted an official "Policy on Payments for Ecosystem Services" in 2013, wherein precedence was to be given to community-managed resources in the negotiation of new agreements (Government of Himachal Pradesh 2013).

We contribute insights into the divergences between PES policy (and theory) ideals and on-the-ground practices. We focus on the socio-political relations, land-use practices, and institutional changes required from an upstream community for the continued operation of a contractual PES agreement for the protection of a microwatershed. In our empirical context, upstream communities are managers of a forest from which a small town in the lower Himalaya derives some of its drinking water source. We investigate the development and implementation of a PESlike agreement in a mountainous environment wherein the availability of alternative water sources is more limited. Heterogeneities and differences between community members in relation to livelihoods, interests, personal connections and preferences, aspirations, and levels of trust result in ongoing challenges to collaboration and collective action, despite userfinanced programs being typically better targeted and often tailored to local conditions (Asquith et al. 2008, Wunder et al. 2008, Wunder 2013, Kerr et al. 2014). PES contracts risk ignoring or oversimplifying complex local political economy and as a result could precipitate new conflicts, especially when monetary or other forms of compensation result in differential outcomes within the community (Kerr et al. 2014), thereby undermining future collective action.

It is recognized in the literature that the negotiations to establish PES-like schemes are political (Hope et al. 2007), but there is little detailed exploration of those politics (Corbera et al. 2009). An uncritical embrace of PES that neglects how politics, culture, and economy govern implementation could reinforce existing power structures, inequalities, and vulnerabilities (Corbera et al. 2007a, $b$, Pascual et al. 2014). Design of PES for watershed services requires negotiation with multiple stakeholders-providers, beneficiaries and intermediaries-who often have varied, sometimes conflicting, positions (Hope et al. 2007). Evidence from Indonesia, the Philippines, and Nepal suggests that negotiations over PES schemes to develop a shared understanding of the diverse interests, assets, capacities, and power of players can take significant time, as does the building of trust between stakeholders (Dietz et al. 2003, Meinzen-Dick 2007, van Noordwijk et al. 2008). Experience with decentralized forest management demonstrates that the political influence of winners and losers from such negotiation processes have a long-term effect on the design, implementation, and impact of interventions (Ribot 2009, Poteete and Ribot 2011). As environmental, socioeconomic, and political contexts change over time, the signals created by incentive-based mechanisms can also change (Jack et al. 2008). Schemes developed through external project and institutional support require a thorough appreciation of local contextual nuances and relations, and appreciation of the capacities, and (usually short-term) commitments of intermediary organizations.

In the case of Palampur, imbalanced power relations exist between the urbanizing, wealthier town with its formal governance institutions capable of raising revenue as well as representing the towns' needs, and the upstream communities, who have a rural council, called the Panchayat, but no equivalent singular representative body with a role in overseeing forest or water management. Intra-community conflicts and divergent interests further undermine efforts for building collective institutions, which have been seen to be of central importance for the longterm adoption and support of conservation-oriented PES agreements, particularly in environments with weak formal institutions (Clements et al. 2010). The task of organizing stakeholders, agreeing to acceptable contractual terms, instigating monitoring and compliance activities all constitute a significant long-term and ongoing challenge. In this paper, we also problematize our own roles as external intermediaries, instigators, and researchers of the PES-like intervention that we have described here. Most PES schemes do not develop spontaneously between service users and providers, and external facilitators have interests and obligations that are tied to achieving project objectives that may be distinct from community interests (de Groot and Hermans 2009, Wunder 2013). Indeed, although communication and trust are bases for collective action, and as outlined above require time, externally instigated PES interventions may neglect to prioritize the nurturing of long-term community institutions. In the present case, new upstream community institutions for forest were formed (and older ones disrupted) to contract with Palampur town for the provision of water services within the PES agreement, leading to complex political dynamics within the villages.

We trace the development and life of a user-financed and externally facilitated reciprocal water access (RWA) agreement (Wunder et al. 2008, Martinez et al. 2013) between downstream water users in the small town of Palampur in the Himalayan foothills, and communities in three upstream hamlets. We focus on the complexities encountered within the upstream community and the effects of maintaining an ongoing ecosystem services payment scheme.

\section{METHODS}

We draw on research and engagement in the town of Palampur and upstream villages from 2004 to 2014, a period punctuated by the adoption of the RWA in 2010. One of the authors (CA) was involved in the original surveys and the development of the Palampur Water Governance Initiative (PWGI) between 2009-2010. From 2011, the implementation and impacts of the RWA were studied as part of a research project on the political economy of negotiations around environmental management interventions in India, funded by the UK's Ecosystem Services for Poverty Alleviation (ESPA) program, involving other authors 
(CK, CA, WA, RH, BV). A follow-up research project on understanding water security and livelihoods in the Himalayas provided the rest of the authors with opportunities to continue to monitor and study the evolving political dynamics at the site (EKK, BV, CA).

We draw on a range of data. First, a household questionnaire was undertaken with $62 \%(\mathrm{n}=37)$ of upstream village households (total household $n=60$ ) in three settlements surrounding Bohal spring (Fig. 1) to understand the demographic profile of the hamlets and explore households' use of forests. Our sampling strategy was nonrandom, as a full census of the three villages was attempted but not achieved because of the limited availability of respondents. Second, a series of five open village meetings were held during 2011 and 2012, attended by a total of 33 people, who had also completed the household questionnaire, during 2011. Third, in-depth interviews were conducted with representatives of local organizations facilitating the Palampur Water Governance Initiative (2010-2012, 2014). Although sampling in 2011-2012 could not cover all households in the upstream villages, the questionnaire, open meetings, and interviews provided complementary insights into the relationships within and between villagers and their use and access of the local forest. We have also observed and recorded local land-management practices and forest use as an outcome of our decade-long engagement at Palampur, such that we are confident that the sampled villagers are representative of the diversity of forest access patterns and needs in the upstream catchments.

We adopted an interpretive and grounded approach to data analysis. The qualitative insights from village meetings and interviews helped to unpack the interests and motivations of the main stakeholders associated with the RWA scheme, and to generate an interpretation of secondary data sources, such as project reports and planning documents. The survey data was used to supplement these interpretations and to provide greater depth of understanding and explanation.

\section{OVERVIEW OF THE RECIPROCAL WATER ACCESS AGREEMENT}

Palampur is located in the Kangra district of Himachal Pradesh in the western Himalayas in India at the foothills of the Dhauladhar mountain range (Fig. 1). The estimated population of the Palampur Planning Area, which includes Palampur, is 46,224 . The town receives an average rainfall of $2500 \mathrm{~mm}$ per year, of which over $80 \%$ falls during the three months of the summer monsoon (Kaul et al. 1993). Hydrologically, the high ranges of Dhauladhar above the town are of critical importance because winter showers and melt from snow and ice from these ranges ensure year-round flows to the Neugal River, which supplies most of the water to the town.

Palampur town obtains water from four sources: a canal (a $\left.k u h l,{ }^{[1]}\right)$ and pipeline from the Neugal River; a small stream (Bagha nala ${ }^{[2]}$ ); a spring in Bohal village; and a few electric and hand pumps that extract groundwater in different locations of the town. The Irrigation and Public Health Department (IPH) manage bulk water supply and treatment from the Neugal River via canals and pipelines, while the Municipal Council (MC) of Palampur manages the Bohal spring and pipelines. The MC manages the distribution of all water including the spring supply to and within the town. The MC purchased the land surrounding the Bohal
Spring source around 1952. Bohal spring water is not mixed with water from other sources, but supplied to the town center area. Its relative importance has been declining to Palampur town in volumetric terms, because it formed the majority of the supply in the 1980s, while today it accounts for only about $15 \%$ of the drinking water network (C. Agarwal 2010, unpublished manuscript; interview, 2014). The promise of clean water and its regular supply to central areas of the town remain politically important issues during local council elections and influence the perceived importance of the $\mathrm{MC}$ as an institution within Palampur, especially as the MC holds the bulk payments to the IPH to be too high (interview, 2014).

Fig. 1. Map of Palampur town and surrounds, including Bohal Spring and the location of three settlements to the northeast of the town.

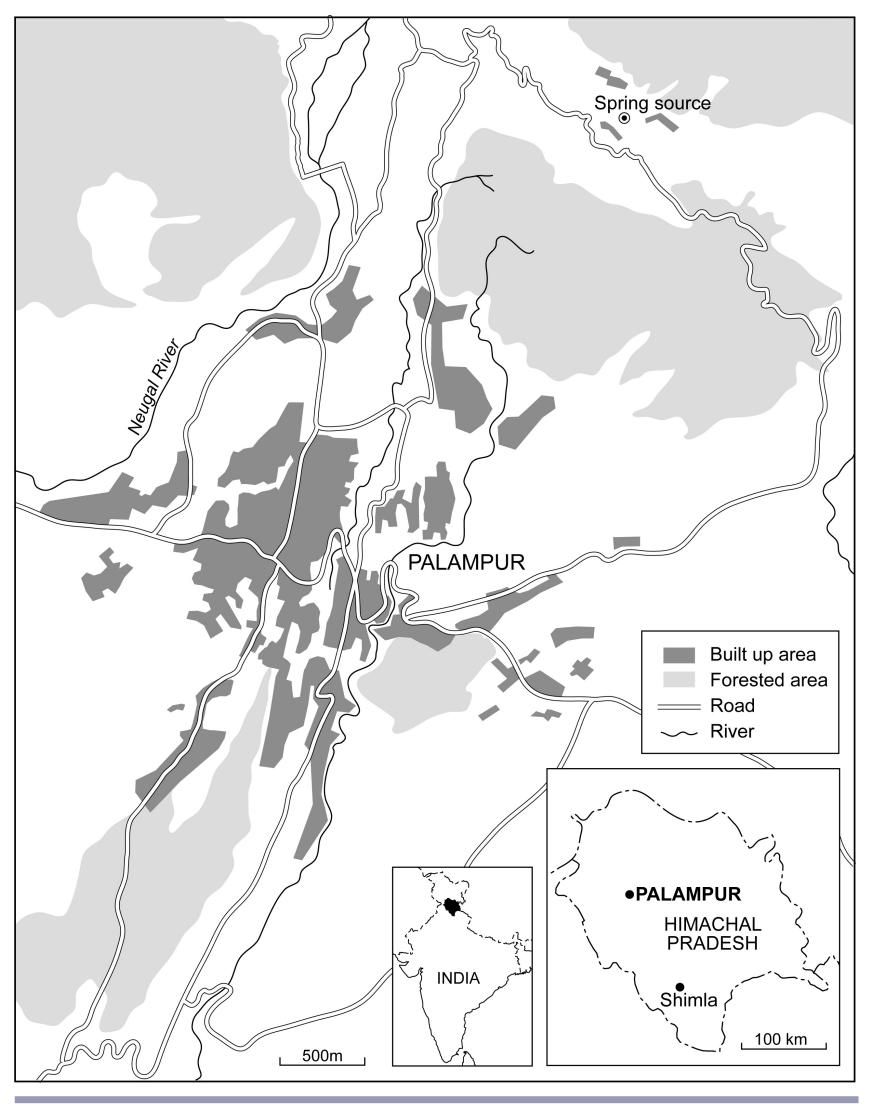

\section{FOREST MANAGEMENT AND INSTITUTIONS AT BOHAL}

The upstream settlements Bohal, Mandai, and Odi, the service providers of water to Palampur, comprise a total of 60 households (Odi is biggest with 27; Mandai smallest with 10 households). The villagers are mainly of the pastoral Gaddi community who now also practice settled agriculture. The forest under which the spring recharge zone is located was originally village common land, used by the community for fodder, leaves, firewood, and timber. The Himachal Pradesh Forest Department regulates use of forest land in Himachal Pradesh. The forest area used by villagers, locally called Bheerni Forest, is officially classified as "undemarcated 
protected forest." Rights of local use were codified in 1895, which gave the villagers of Bohal, Mandai, and Odi rights to collect forest produce for their own use. The forest subsequently became degraded, and the Forestry Department undertook Social Forestry Projects (C. Agarwal 2010, unpublished manuscript).

Because men often migrate either for work or to be with cattle, women primarily undertake collection of forest products, and have historically managed forests. The household survey revealed that use and dependence of forest products was high among villagers. The most important forest product was firewood $(65 \%$ of respondents). Annual firewood consumption was about 3700 $\mathrm{kg}$ per family ( $10 \mathrm{~kg} /$ household/day). Leaf fodder was the second most important resource, each family collecting an average of $1100 \mathrm{~kg}$ annually. Community forest protection had begun in 1999 , and $89 \%$ of respondents said that firewood availability had increased since that time, and expected that continued protection would maintain fuelwood supply. The most important indirect benefit of the forest was reported to be its role in retaining water and hence offering protection from flash floods.

Local narratives suggest that the extensive oak and rhododendron forests started degrading from overexploitation over the past few decades. In 1999, the women from Bohal and Mandai village who had formed a Mahila Mandal ${ }^{[3]}$ (a village women's group) decided to regulate extraction of forest products and to protect the forest. The forest protection was in response to two key factors. First, deforestation was believed to exacerbate the effects of flash floods, which caused massive damage to crops and houses in Bohal in 1997. Second, the village women wanted to stop the people from neighboring Jhanjara village from using the forest (because their use had increased with closure of the forest adjoining their own village because of a plantation project implemented by the Forest Department). Subsequently, women from Odi village also formed a Mahila Mandal, and the groups decided to hire a forest guard $\left(R a k h a^{[4]}\right)$ to protect the forest. The Rakha was paid in both cash and in kind, e.g., in grain. As one woman explained,

When we started protecting the forest, women from Odi also showed interest ... they suggested to keep a Rakha to protect the forest as Mahila Mandal members cannot protect the forest on their own. We all realized that we should keep one and everyone started contributing ten rupees [per month] for keeping the Rakha. (participant-2, Village Meeting-1, 2011)

Although the Mahila Mandal protected the forest, they did so without formal recognition or support from the Forest Department or any other government agency. They also fully closed the forest because no harvesting of fuelwood or fodder was allowed, on the logic that the degraded forest needed time to recover. Forest condition improved gradually, but there were renewed pressures for local use from both within and outside the village. Because the Rakha was not recognized by the Forest Department, it was difficult to enforce restrictions and impose penalties on violators. For example, one respondent observed that, "there were a few families who did not contribute but often went to the forests" (participant-3, Village Meeting-1, 2011). Further, there were frequent conflicts between the members and the guard. One respondent observed that, "the guard allowed certain families to collect products from areas where the forest was in good condition and restricted others" (participant-4,
Village Meeting-1, 2011). Occasionally, there were disagreements between members about collection and expenditure of funds, which also related to underlying issues of management transparency. There were also instances of outsiders questioning the authority of the Rakha to stop them from using the forest, which in turn challenged the basis of protection by the Mahila Mandal. Thus, when the RWA scheme was proposed, there was a perceived need among villagers to improve the system of forest protection and to give it formal recognition. Equally, indications of latent conflict within the village community were already visible at this inception stage of the RWA, particularly in relation to the pre-existing institutions for forest management, the role of the Rakha, and perceptions of selectivity in the application of rules to different families and forest users.

\section{INITIAL NEGOTIATION PROCESS: DESIGNING THE RECIPROCAL WATER ACCESS AGREEMENT}

\section{The Water Governance Initiative}

The Palampur Water Governance Initiative (PWGI) arose from a collaborative project between the German Development Agency GIZ and the state Government of Himachal Pradesh, under the project "Capacity building of Panchayati Raj Institutions in Himachal Pradesh" (2007-2011). This aimed to better enable the legal and institutional decentralization of environmental management, particularly of water. Previous work had been undertaken in 2004 by the International Institute for Environment and Development (UK) and Winrock International India, who led an action-learning project in Himachal Pradesh "Fair deals for watershed services in India," exploring the potential for incentive-based mechanisms (Agarwal et al. 2007). Palampur emerged as a promising site for a PES-like scheme, with strong local institutions, functioning community arrangements for forest protection, as well as interest from both up- and downstream stakeholders (Agarwal et al. 2007).

Members from the earlier project allied with a local organization based in Palampur, the Himachal Pradesh Eco-Development Society, and with support from the GIZ, started the Palampur Water Governance Initiative (PWGI; see Fig. 2) to increase interaction and trust between different stakeholders and to identify and implement measures to improve water quality and enhance water quantity. The PWGI facilitation team undertook a feasibility study in 2009 to explore the needs of upstream villagers and the downstream town, and to identify potential for a PES-like scheme to improve water management. The downstream perspective was captured through a roundtable meeting attended by the Municipal Council, the Irrigation and Public Health Department and the Forest Department (see Fig. 2).

The 2009 study identified two problems: first, the effects of increasingly erratic patterns of water supply, attributed partly to reductions in local rainfall and snowfall, on discharge from springs and streams, especially in the nonmonsoon dry summer months (C. Agarwal, S. Prasanna, and Himachal Pradesh EcoDevelopment Society 2009, unpublished manuscript); second, long-standing water quality issues during the monsoon period as a result of high silt loads in the Neugal River caused by increases in sediment and debris associated with construction of an upstream hydropower project. These changes increased the cost 
of water treatment and extended the annual shut down for storage tank maintenance, such that (even today) the MC remains in an ongoing dispute with the Irrigation and Public Health Department over the rate of water fees charged to the town from the river. In this context, the Bohal Spring offered an alternative source of relatively clean water for which the MC did not have to negotiate with or pay the Irrigation Department.

Fig. 2. Stakeholders involved in the Palampur Water Governance Initiative (PWGI).

\begin{tabular}{|c|c|c|c|c|}
\hline & \multicolumn{3}{|c|}{ Palampur Water Governance Initiative } & \\
\hline $\begin{array}{c}\text { HP State } \\
\text { Government }\end{array}$ & $\begin{array}{c}\text { Local } \\
\text { Government }\end{array}$ & NGOs & External agencies & $\begin{array}{l}\text { Research } \\
\text { projects }\end{array}$ \\
\hline $\begin{array}{l}\text { - Forest } \\
\text { Department } \\
\text { - Irrigation and } \\
\text { Public Health } \\
\text { Department }\end{array}$ & $\begin{array}{l}\text { - Palampur } \\
\text { Municipal } \\
\text { Council } \\
\text { - Gram } \\
\text { Panchayats } \\
\text { - Mahila Mandal } \\
\text { in Bohal } \\
\text { - Village Forest } \\
\text { Development } \\
\text { Society }\end{array}$ & $\begin{array}{l}\text { - Himachal } \\
\text { Pradesh Eco- } \\
\text { development } \\
\text { Society }\end{array}$ & $\begin{array}{l}\cdot \text { GIZ } \\
\text { - Independent } \\
\text { hydrologists: } \\
\text { ACWADAM } \\
\text { India }\end{array}$ & $\begin{array}{l}\text { - International } \\
\text { Institute for } \\
\text { Environment } \\
\text { and } \\
\text { Development } \\
\text { (IIED) } \\
\text { - Winrock } \\
\text { International } \\
\text { India (now } \\
\text { InsPRE } \\
\text { Network for the } \\
\text { Environment) } \\
\text { - ESPA project on } \\
\text { negotiations for } \\
\text { water (2011-12) } \\
\text { - ESPA project on } \\
\text { water security } \\
\text { and livelihoods } \\
\text { (2014-16) }\end{array}$ \\
\hline
\end{tabular}

Negotiation of the RWA required "intense effort[s]" by the facilitation team (C. Agarwal 2010, unpublished manuscript). The personal expertise and interests of facilitation and staff in establishing a functional incentive-based mechanism, the willingness of stakeholders, and the positive upstreamdownstream relations at Palampur all lent themselves to the establishment of the agreement, which was signed by the Palampur MC and the Bohal-Odi Village Forest Development Society in October 2010. It required the protection of forests led by the Mahila Mandals to transition to a new Village Forest Development Society to manage the Bohal forest, and continue to control forest product harvesting in order to protect the catchment of the Bohal spring. The Palampur MC, as the direct beneficiary of the water recharge services, committed to pay a sum of INR 10,000 ( US\$160) per year.

\section{Negotiations with downstream actors}

The majority of the members of the executive committee of Palampur MC contacted by the facilitation team in 2009 were interested in securing the long-term source sustainability of the water supply from Bohal spring. However, they were not sure which part of the upstream forest comprised the infiltration zone of the spring, and whether its protection would actually improve discharge. The MC insisted on a scientific assessment before backing the idea of a PES-like intervention with public funds, as previously they had obtained spring water from Bohal for free. Accordingly, a rapid geohydrological study was carried out by an independent consultant hydrologist. They identified a zone within the forest near Bohal with high potential for infiltration and groundwater recharge (manuscript). A presentation of this assessment to the MC and submission of the report was found to be sufficient by the then-President and other executive members of the MC, as well as the facilitation team. As the ex-President of the MC said,

\begin{abstract}
Within the MC some members raised the question that we had already bought the water many years ago so why should we pay for it now? We convinced them that this was a good effort and then when the hydrologist gave the report they were ready to do anything. (interview, 2011)
\end{abstract}

The hydrologist's report convinced the MC that a small payment for forest management would be a worthwhile investment, particularly in light of the difficulties upstream communities had experienced in the past in limiting forest access. The consultant recommended continuous monitoring of the Bohal Spring discharge and discussions with upstream villagers about institutional mechanisms for forest protection. The MC needed to be convinced that there were institutions in the village that had the authority and capacity to control forest access and use, and that would implement the proposed RWA agreement.

\section{Negotiations with upstream actors}

In 2009, the three villages were divided over future forest management. Some people wanted to continue protection while others wished to restart logging, although all parties were concerned about the long-term viability of forest resources. The facilitation team introduced the idea of a registered village forest protection group to manage the forest and implement a long-term management plan, and a PES-like RWA scheme to reflect the assumed relationship between forest state and water supply. The hope was that the new upstream village forest protection group, which had members from all three (Bohal-Odi-Mandai) villages near the Bohal spring, would continue the protection of the forests and implement the rules and bylaws to manage the forest, to both meet the needs of the village communities and provide the basis for an agreement with the Palampur MC.

In 2009-2010, the PWGI team held detailed discussions with various members of the Mahila Mandal about the Bohal spring head and the forests. There were conflicts between members of the Mahila Mandal and the Rakha, challenges in enforcing protection within the community, and formal legitimacy requirements from the perspective of the Forest Department. These problems, and the administrative requirement to take up the delegated protection responsibilities under the state level regulations for Participatory Forest Management, with the ability to exclude outsiders, led the facilitating team and the Forest Department to decide that a new Village Forest Development Society (VFDS) should be formed to protect the forests, rather than using the existing Mahila Mandal. The VFDS could be legally recognized by the Forest Department, be authorized to manage and protect the forests, and receive grants for forest management. At the same time, the VFDS, with a locally elected executive committee and a local member secretary, would answer to its membership rather than to the Forest Department. Members of the VFDS comprised all households of the villages that required fuelwood or access to the forest. Each member of the VFDS was required to pay an annual fee of INR 100 (US\$1.60 at 2015 exchange rates) to pay a Rakha for forest protection. The VFDS Executive Committee was given powers to impose a fine for any violation of rules. The prospect of the VFDS as an autonomous, formally recognized institution with powers to enforce protection also encouraged women to take part in discussions on negotiation for the RWA because of women' active history of leading in forest management. However, these decisions were promoted and fulfilled as a result of the facilitation efforts 
of the external PWGI team (and to the timeframes of the GIZsupported project), and did not emerge "organically" as an outcome of local political dynamics and timeframes (c.f. Clements et al. 2010).

In 2010, the Bohal VFDS was registered as a village organization following the Himachal Pradesh Participatory Forest Management rules of 2001. An ad hoc VFDS executive committee of 10 members was nominated by villagers (four from Odi, three from Mandai, and three from Bohal), and elected in a joint meeting of the three villages. There were two important features of this process. First, women were in a majority at the meeting, because of the gendered nature of forest responsibility for fuelwood collection and management, and the men who had been nominated opted out, resulting in a women-only committee (GIZ 2011). Second, control of forest management passed from the Mahila Mandal to the new VFDS executive committee, under a new president. Previous Mahila Mandal office bearers were excluded from holding positions in the new committee because of their still extant role in management of the Mahila Mandal, and it was felt that the same individuals should not lead both groups. However, a consequence of this was that the VFDS became headed by younger women with less experience, and rendered the role of the older Mahila Mandal in forest protection and as a management institution somewhat obsolete. Both these processes had subsequent impacts on the internal political dynamics within the upstream villagers, and levels of internal cohesion and trust, which are critical to the longer term sustainability of the RWA agreement.

The facilitation team simultaneously discussed a 20 -year plan to manage the forest (and thereby, in theory, protect the Bohal spring recharge zone) with the residents of all the three hamlets including the VFDS committee members. This was done separately in the three hamlets, to identify differences and preferences over practical forest management. There was common agreement among villages about the need to protect the forest, and to start some level of controlled harvesting after years of no harvesting; however, there were differences regarding the level of harvesting and the nature of restrictions on forest use. Consensus was arrived by accommodating one or the other demand of each hamlet, for example by adopting Bohal's suggestion of 15 days for leaf fodder collection but Mandai's suggestion of seven days of grass collection. It was also decided that the forest would be divided into three zones for controlled rotational harvesting, so that each block of the forest got two years' rest and recovery before a harvest. The facilitation team held a final meeting to review and finalize the agreement and subsequently prepared draft bylaws based on an available template of bylaws for Himachal Pradesh Participatory Forest Management rules, which included provisions for PES agreements. The bylaws were discussed and finalized in consultation with all the stakeholders. There was no significant involvement of Palampur Municipal Council in the formulation of bylaws and rules for forest management or the Management Plan; the downstream stakeholders were not actively concerned about the needed land-use changes and requirements to be undertaken by the upstream.

\section{Payment levels and conditionality}

Once the VFDS was established, and the forest management plan agreed, the facilitation team drafted the Reciprocal Water Access agreement, based on the inputs from the VFDS Executive Committee, village consultations, and the Palampur Municipal Council. The Council was reluctant to pay for forest protection by villagers because revenue from water supply in Palampur was insufficient to meet operational and maintenance costs. Further, there was very little information (or information considered reliable) either on the value of water to Palampur consumers from the Bohal spring, or the opportunity costs of not deforesting the area around the spring. After several rounds of discussions between the MC and VFDS, facilitated by the project team, a payment of INR 10,000 (US\$160) per year with a 10\% increase after every five years was agreed. Furthermore, if the forest was not adequately protected, then the MC reserved the right to issue a notice to make amends, and terminate the agreement if amends were not made.

To receive the payment, the VFDS had to protect and manage the forest area in accordance with the forest management plan and RWA prepared by the facilitation team. Monitoring was kept simple. The VFDS agreed to invite the MC for a joint "walk" to the spring recharge zone twice a year, once in spring or summer and once after the monsoon, to make a visual assessment of the condition of forests. They would then jointly sign a report on forest condition and the VFDS would raise an invoice for payment. Any concerns were to be addressed in the following year and the payment for the next year would be based on the evaluation of the agreed measures.

\section{OUTCOMES, INSTITUTIONAL ARRANGEMENTS, AND CONFLICT}

The RWA agreement has remained in place since 2010. From the perspective of the downstream Municipal Council, it has been a relative success. As of June 2014, the MC had not received a single complaint about the quality or quantity of water to houses in the town for at least six months, and there was a general perception among officials interviewed that the quantity of the water discharge had increased from the spring source, though this is empirically unverifiable. The MC has elected to forgo any formal monitoring checks of the forest area; local contacts and interactions have been sufficient to assure the $\mathrm{MC}$ that the forest is being maintained. As mentioned by office bearers of the MC, they can see the forest from the MC office and it looks green and healthy even from afar.

In contrast, in the four years following implementation, the situation at the three villages has evolved less smoothly in relation to the forest protection institution. Although a formal guard was not in place for most of 2013-2014, most upstream villagers interviewed in 2014 felt that the forests were being protected by the community, and there was indeed no visible large-scale damage or felling. However, the earlier focus group discussions in 2011 had already revealed increasing disagreement between various groups within and between the villages about the extraction of products such as leaf fodder from forests required by the RWA; some villagers thought that more leaf fodder could be sustainably extracted; the lopping would also reduce fire hazards. The continuation of restrictions on grazing under the RWA also led to conflicts over traditional rights of grazing in the forest area because some families in the village still keep large herds of 400-500 sheep and goats. When the VFDS imposed a fine on one family for letting some goats graze freely, one villager 
let the herd into the forest when he was moving downhill during the winter. A number of people frequently sent their cattle to the forest for grazing and did not pay the fine if imposed by the VFDS in the post-2010 period (personal observations, 2011-2012). Such disregard for the rules was attributed to the wider disagreements between the Rakha and the VFDS committee and the persistent questions around the destination of payments from villagers to the Rakha, with money in the VFDS fund from its members, as well as Palampur MC's annual RWA payment.

In addition to the annual revenue from the MC under the RWA, the VFDS also collected a monthly fee from its members (initially Rs 10/mth, then Rs 20), which was to go to the Rakha. However there have been accounting gaps that have given rise to misunderstandings that have undermined the functionality of the VFDS and the authority of the Secretary. In addition, a conflict with a hydropower firm over construction of electric line pylons in the forest went to the local court and led to further stress on key members of the VFDS, and regular executive committee meetings or general body meetings of the VFDS were discontinued for almost a year. Thus, in 2014, no member of the VFDS interviewed knew precisely if previous years' payments had been made. On the one hand, this suggests that the payment is relatively insignificant to either the VFDS or the hamlet communities, and that forest protection is ongoing out of a genuine recognition by villagers of the need to protect their resources. However, the gaps in the revenue from the local monthly contributions has also exacerbated community tensions around financial management, safeguarding, and transparency and accountability.

Focus groups and in-depth interviews in 2014 revealed different interests in and concerns about the RWA agreement. There was discontent among some old members of the Mahila Mandal who were not included in the VFDS executive committee. During the negotiation and the initial postagreement phase, the new VFDS executive members were invited to meetings by the facilitation agencies and interacted regularly with MC officials, forest officials, and research and NGO groups. This new-found status of executive committee members may have reduced cooperation with other executive members of the pre-existing Mahila Mandal. For instance, during one of the meetings, a Mahila Mandal member said,

\begin{abstract}
We have more conflicts since the creation of VFDS and it is increasingly difficult to stop people from using the forests... it might perhaps help to divide the forest into three parts and form a separate VFDS, rather than a combined one. (Village Meeting-1, 2011)
\end{abstract}

Some members also complained about the payment of INR 100 as the membership fee to VFDS in addition to the to the INR 20 fee to the Mahila Mandal,

\begin{abstract}
It is an extra burden to pay INR 100 and also protect the forest... Sometimes we cannot pay the money, we are poor people. (Villager-1, Village Meeting-2, 2011)
\end{abstract}

During 2012 a hydropower company built electricity lines through the community's forests, which led to an extended court case. VFDS members were accused of extortion and had to legally defend themselves and challenge this development. This case led to an initial consolidation within the village, with key male residents and members of the earlier Mahila Mandal taking on an active supporting role in the defense of the accused VFDS members during the Court proceedings, with support from an environmental activist active in the area. However, the case stretched to almost a year with numerous hearings. After the case was settled in late 2013, the VFDS received a monetary transfer of INR 100,000 as settlement. Part of this money was distributed to the five individuals who had been targeted in the case and had invested both time and/or money in representing themselves and the community in court, divided so that each received INR 5000. Lawyers' fees amounted to INR 16,500, and the remaining funds were left in the VFDS bank account (verified by authors CA and EKK). However, in the wider community there was a perception that the sharing of funds was done unilaterally without community concurrence and lacked transparency. Many believed that the entire sum had "disappeared" or had been misappropriated. As a result of the fallout from this case, the President of the VFDS felt that she had "had enough" and even suggested that she wished to pass the post on to others (interview, May 2014).

The dominance of women on the VFDS committee was also referred to increasingly as a point of conflict in interviews conducted with villagers after 2012. For example, there was an informal group of young men in the village (a youth club) that had no formal link with forest protection. After completion of the RWA agreement, they became vocal and critical of the agreement, saying "women have sold the forest ... why should we pay and protect the forest?" (member of Mahila Mandal, participant-1, Village Meeting-1). During focus group discussions, one young man said "it is fine that a VFDS is formed but in the next election we will not give powers to the women; the committee will be of men only" (male youth club member, Village Meeting-2). Many villagers said that they were not aware of the bylaws and the actual content of the RWA agreement, except that the village would receive money. One young man said, "As in 1952, our forefathers were illiterate and our water was bought by the MC from them due to their ignorance and now the same thing is happening..." (male youth club member, Village Meeting-5). Another villager contributed, "We did not pay much attention to the meetings as we thought it was for women only ... we did not have the knowledge of why and how the VFDS was formed" (Villager, Village Meeting-5, 2012). These disputes and rumours undermined the legitimacy of the VFDS and its ability to function for a time. As one VFDS member summarized, "People say that we have sold our forests and not that we are trying to stop them from using it the way they have been in the past" (VFDS member, Village Meeting-1, 2011).

The gaps in facilitation support led to no engagement with the village over 2013-2014, beyond some informal engagement. This absence and narrow communication channels with only some members of the village population, and in particular with the elected members of the VFDS by the researchers may, to some extent, have contributed to the heightened conflict and feelings of exclusion by community members. Information flows can be highly problematic within villages, where word of mouth and developed social relations and their accompanying alliances and prejudices easily lead to misunderstandings. As recounted above, at Bohal the RWA agreement led several villagers to hold the impression that the forest area had been "sold" to the Palampur 
Municipality, and many claimed not to know where the received annual payment was destined. These developments meant that the VFDS committee was close to dysfunctional for part of 2013 and 2014, however both the upstream community and downstream MC agreed that the forest was by and large protected and the VFDS was eligible to receive payments from the Palampur MC.

\section{DISCUSSION}

Since the signing of the RWA agreement in 2010, developments in Palampur town and its surrounds have included the growing presence and pressure of hydropower interests and new infrastructure. ${ }^{[5]}$ The lives, opportunities, and thus decisionmaking frames of villagers in the hamlets have also changed. As a result, the RWA must be understood as one element of an everchanging socio-political landscape where land claims and uses continue to evolve and exert changing pressures on existing practices and agreements. In this context, the negotiated and agreed opportunity cost of the RWA agreement becomes just one element of a much more complex and dynamic social reality. It is important to understand the social networks and linkages that reinforce the need for embedded social negotiation of PES-like contracts, as was done here, rather than the introduction of standardized templates developed elsewhere (Kolinjivadi et al. 2014). Agreements must take into account historical costs and duties for the management of the same resource, or risk creating new conflicts that lead to resistance and dissent.

We have presented evidence that demonstrates how disparate the stakes of up- and downstream communities are in the management of a small watershed. Although buyers must be convinced of the importance of the water-forest service to be willing to buy, sellers in the upstream areas must not only modify extant land-use practices, but be willing to accept leadership and authority from both within and outside the community to manage their resource, often with competing objectives. Based on our experience at Palampur, although the agreement included basic conditionality and monitoring elements in the design and maintenance of a PES-like scheme, satisfying conditionality in practice and verifying impacts of payments were of little interest to either upstream or downstream actors (evidenced by the cessation of monitoring activity on the withdrawal of research and project attention at Palampur in 2012). A rapid technical hydrological assessment proved to be sufficient evidence for both research teams and local communities to begin implementation of the RWA. Similarly, local autonomous interest in forest protection is a demonstrably powerful motivator for continued forest protection because although the upstream community kept a local forest guard to protect the forest, protection continued even when the guard was not in place. This raises interesting questions about the necessity of financial incentives for maintaining the protection of upstream watersheds, as opposed to the role of monetary transfers to initially catalyze such agreements, where there may be little motivation for, or evidence of, pre-existing protection activity.

The implementation of PES in Palampur was the result of a complex negotiation process. The initial GIZ-supported facilitation process successfully negotiated the agreement between Palampur MC and the upstream hamlets, and enabled the formation of a new upstream institution, the VFDS, to take over the forest protection responsibility from the women's group (Mahila Mandal) and contract with the MC. However, at the end of the project timeline the facilitation team withdrew, leaving the upstream community without advisory, institutional, or practical support to help the newly formed VFDS and wider community maintain and enforce the forestry practices required. Subsequently, two ESPA-supported research projects have led to some informal facilitation and support of the VFDS by field staff during the course of the research, but intermittently, as this is not the main focus of these projects. At village meetings two years after the signing of the contract, field staff had to remind villagers that their role was "only to facilitate the agreement and capacity building as mandated by the [original] project" (field notes, 2012). Furthermore, negotiation capacities of local communities need development and support, because at Palampur some of the cobenefits discussed at the negotiation phase of the contract promising sanitation and education have not occurred, because of responsibility falling entirely on the newly created and overstretched VFDS group to realize these additional potential benefits. When local cultural and social acceptance drives the success of PES contracts (Kolinjivadi et al. 2015), the importance of social cobenefits may be high, which are in keeping with the ambitions of PES to both enhance particular ecosystem services and to alleviate poverty and improve well-being (Corbera et al. 2007a,b, Gauvin et al. 2010, Fisher et al. 2013). Our experiences in Palampur demonstrate the importance of providing long-term advice and support to newly contracting parties to enable the realization of management goals as well as capacity-building that is likely to enhance communities' abilities to respond to developments, such as the expansion of hydropower interests in the present case.

Two further elements emerged from the negotiations and postagreement implementation and political engagements. First, the experience of the facilitation process with the sellers in Palampur suggests the need for a better understanding of local politics and greater effort in consensus-building in organizing upstream stakeholders. Here, the rapid creation of an all-women VFDS became problematic with time and a source of mistrust within the hamlet communities as a result of a lack of transparency with the disbursement of funds from the hydropower settlement, and a lack of clarity among villagers about where the yearly MC payments were going. PES projects in these contexts can benefit from building more participatory (consensus) mechanisms for enforcement and decision making that grasp local dynamics and complexities. The task of facilitation in such cases is to better understand these processes, and identify and support community mechanisms for transparency and conflict prevention and resolution.

Second, the fact that the payment was small and had a relatively small impact on the income of both providers and buyers has a number of implications. As buyer, the MC's main interest in securing the protection of the catchment of the Bohal spring to provide part of the town's water supply was influenced and formed by competing concerns, on the one hand to continue to meet the supply needs during critical monsoon months and to perhaps demonstrate its ownership of the spring source, and on the other, the politics of the local elections. The way the amount of payment was determined challenges the economic foundation of PES design principles. For the villagers, the direct benefits of 
controlled harvesting of forest products, continued community forest management and control, and the indirect assumed benefit of protection from flash floods were the main incentives for protection, and the payment provided an additional financial benefit. Because they were already protecting the forests, the initial additional cost was low. However, the introduction of a high(er) membership fee to the management committee placed extra burdens on the villagers, who had decided to save the payment under the RWA in their bank account, rather than use it for protection or distribution. Further, those who participated in the VFDS were already committed to forest protection, while others who also affect forests, like graziers, were not well represented, such that the focus of negotiations and the agreement ignored other important relationships and users, and how they may need to be accommodated or compensated. Thus at the community level, payments do not address the concerns (and costs) of those stakeholders who bear higher impacts than others. This imposed limitations on the RWA agreement as a conditional and negotiated instrument to secure watershed services in Palampur.

The case of protecting forests and critical water zones in Palampur demonstrates the need for an explicit understanding of how to empower communities so that they can realize effective resource management through deliberative intra-community consultation and representation. The incentive and governance arrangements that prevail both in the upper catchment and in small towns are critical to determine the potential for compensation-based schemes for the supply of ecosystem services more generally, and especially in the perceived importance of these schemes from the vantage of upstream sellers. As similar arrangements evolve and proliferate, there is considerable merit in understanding the longterm political economy dynamics in local transacting communities, which influence the outcomes and sustainability of such interventions.

\footnotetext{
${ }^{[1]}$ Kuhl, a small, local, gravity-fed canal drawn from river/stream; it may be earthen or lined, and managed locally or by the IPH.

${ }^{[2]} \mathrm{Nala}$, the local term for a stream or small river; may be seasonal or perennial and often used interchangeably with the term khad.

[3] In Himachal Pradesh, since mid-1990s a number of selfinitiated Mahila Mandals (village women's groups), Yuva Mandals (youth groups), and self-help groups were formed in villages to promote environmental conservation, income generation, and other village development activities.

${ }^{[4]}$ The practice of keeping a Rakha is common in many villages in the Kangra and Palampur districts that have Co-operative Forest Societies, duly recognized by the Forest Department. The main role of Rakha was to enforce rules such as no tree-cutting without the permission of the Forest Department, no grazing in closed areas, and to allow only dry firewood collection. However, the Rakha in this village initially did not have this formal status. [5] These developments in hydropower expansion have had significant social and economic effects on the settlements around Palampur, but have not affected the Bohal Spring catchment.
}

Responses to this article can be read online at: http://www.ecologyandsociety.org/issues/responses. $\mathrm{php} / 8462$

\section{Acknowledgments:}

The 2010-2012 research was funded by the Natural Environment Research Council/Economic and Social Research Councill Department for International Development Ecosystem Services and Poverty Alleviation Programme (ESPA), project reference number NE/I003924/1. Research in 2014 was funded by an ESPA project on the Political Economy of Water Security, Ecosystem Services and Livelihoods in the Western Himalayas, project grant NEI L001365/1. We would also like to acknowledge that UK aid from the UK government through their "Improving the way knowledge on forests is understood and used internationally (KNOWFOR)" grant, awarded to IUCN, provided the funding to publish this article. The authors thank Mr Philip Stickler, Department of Geography, University of Cambridge, for drawing the map, and two anonymous referees for their comments. We would also like to acknowledge the invaluable fieldwork and help of Mr. Vijay Guleria and Mr. Satya Prasanna.

\section{LITERATURE CITED}

Agarwal, C., S. Tiwari, M. Borgoyary, A. Acharya, and E. Morrison. 2007. Fair deals for watershed services in India. Natural Resources Issues No. 10. International Institute for Environment and Development, London, UK.

Agrawal, A. 2001. State formation in community spaces? Decentralization of control over forests in the Kumaon Himalaya, India. Journal of Asian Studies 60(1):9-40. http://dx.doi. org/10.2307/2659503

Asquith, N. M., M. T. Vargas, S. Wunder. 2008. Selling two environmental services: in-kind payments for bird habitat and watershed protection in Los Negros, Bolivia. Ecological Economics 65(4):675-684. http://dx.doi.org/10.1016/j. ecolecon.2007.12.014

Blaikie, P., and J. Muldavin. 2004. The politics of environmental policy with a Himalayan example. Asia Pacific Issues 74:1-8.

Bonell, M., and L. A. Bruijnzeel, editors. 2005. Forests, water and people in the humid tropics. Cambridge University Press, Cambridge, UK. http://dx.doi.org/10.1017/cbo9780511535666

Bruijnzeel, L. A. 2004. Hydrological functions of tropical forests: not seeing the soil for the trees? Agriculture, Ecosystems and the Environment 104:185-228. http://dx.doi.org/10.1016/j.agee.2004.01.015

Calder, I. R. 2005. Blue revolution: integrated land and water resource management. Earthscan, London, UK.

Clements, T., A. John, K. Nielsen, D. An, S. Tan, and E. J. MilnerGulland. 2010. Payments for biodiversity conservation in the context of weak institutions: comparison of three programs from Cambodia. Ecological Economics 69(6):1283-1291. http://dx.doi. org/10.1016/j.ecolecon.2009.11.010

Corbera, E., K. Brown, and W. N. Adger. 2007a. The equity and legitimacy of markets for ecosystem services. Development and Change 38(4):587-613. http://dx.doi.org/10.1111/j.1467-7660.2007.00425. $\underline{\mathrm{X}}$

Corbera, E., N. Kosoy, and M. M. Tuna. 2007b. Equity implications of marketing ecosystem services in protected areas and rural communities: case studies from Meso-America. Global 
Environmental Change 17(3-4):365-380. http://dx.doi.org/10.1016/ j.gloenvcha.2006.12.005

Corbera, E., C. G. Soberanis, and K. Brown. 2009. Institutional dimensions of payments for ecosystem services: an analysis of Mexico's carbon forestry programme. Ecological Economics 68 (3):743-761. http://dx.doi.org/10.1016/j.ecolecon.2008.06.008

Daw, T., K. Brown, T. Rosendo, and R. Pomeroy. 2011. Applying the ecosystem services concept to poverty alleviation: the need to disaggregate human well-being. Environmental Conservation 38 (4):370-379. http://dx.doi.org/10.1017/S0376892911000506

de Groot, R. B. A., and L. M. Hermans. 2009. Broadening the picture: negotiating payment schemes for water-related environmental services in the Netherlands. Ecological Economics 68(11):2760-2767. http://dx.doi.org/10.1016/j.ecolecon.2009.06.008

Dietz, T., E. Ostrom, and P. C. Stern. 2003. The struggle to govern the commons. Science 302(5652):1907-1912. http://dx.doi. org/10.1126/science. 1091015

Engel, S., S. Pagiola, and S. Wunder. 2008. Designing payments for environmental services in theory and practice: an overview of the issues. Ecological Economics 65(4):663-674. http://dx.doi. org/10.1016/j.ecolecon.2008.03.011

Farley, K. A., L. L. Bremer, C. P. Harden, and J. Hartsig. 2013. Changes in carbon storage under alternative land uses in biodiverse Andean grasslands: implications for payment for ecosystem services. Conservation Letters 6(1):21-27. http://dx.doi. org/10.1111/j.1755-263x.2012.00267.x

Fisher, J. A., G. Patenaude, P. Meir, A. J. Nightingale, M. D. A. Rounsevell, M. Williams, and I. H. Woodhouse. 2013. Strengthening conceptual foundations: analysing frameworks for ecosystem services and poverty alleviation research. Global Environmental Change 23(5):1098-1111. http://dx.doi.org/10.1016/ j.gloenvcha.2013.04.002

Forsyth, T. 1996. Science, myth and knowledge: testing Himlayan environmental degradation in Thailand. Geoforum 27(3):375-392. http://dx.doi.org/10.1016/s0016-7185(96)00020-6

Gauvin, C., E. Uchida, S. Rozelle, J. Xu, and J. Zhan. 2010. Costeffectiveness of payments for ecosystem services with dual goals of environment and poverty alleviation. Environmental Management 45:488-501. http://dx.doi.org/10.1007/s00267-009-9321-9

GIZ (Deutsche Gesellschaft für Internationale Zusammenarbeit). 2011. Palampur water governance initiative: application of payment for ecosystem services for ensuring drinking water security in Palampur Town, Himachal Pradesh, India: process and results. Booklet GIZ Office, New Shimla, India.

Goldman-Benner, R. L., S. Benitez, T. Boucher, A. Calvache, G. Daily, P. Kareiva, T. Kroeger, and A. Ramos. 2012. Water funds and payments for ecosystem services: practice learns from theory and theory can learn from practice. Oryx 46(1):55-63. http://dx. doi.org/10.1017/s0030605311001050

Government of Himachal Pradesh. 2013. Policy on payment for ecosystem services (PES) in Himachal Pradesh. Reference no. FFE-B-C(15)-3/2005-II. Government of Himachal Pradesh, Forest Department, Shimla, India. [online] URL: http://hpforest. nic.in/pages/display/NjVzZDRhhXQ0ZjY1cw==-policylaws
Guthman, J. 1997. Representing crisis: the theory of Himalayan environmental degradation and the project of development in post-Rana Nepal. Development and Change 28(1):45-69. http:// dx.doi.org/10.1111/1467-7660.00034

Hope, R. A., I. T. Porras, M. Borgoyary, M. Miranda, C. Agarwal, S. Tiwari, and J. M. Amezaga. 2007. Negotiating watershed services. International Institute for Environment and Development, London, UK.

Jack, B. K., C. Kousky, and K. R. E. Sims. 2008. Designing payments for ecosystem services: lessons from previous experience with incentive-based mechanisms. Proceedings of the National Academy of Sciences 105(28):9465-9470. http://dx.doi. org/10.1073/pnas.0705503104

Kaul, B. K., S. L. Sharma, and R. P. Kaushik. 1993. Eco-analysis of Kangra valley Himachal Pradesh, India. Pages 111-128 in A. K. Tripathi, A. K. Srivastava, and S. N. Pandey, editors. Advances in environmental sciences. Ashish Publishing House, New Delhi, India.

Kerr, J. 2002. Watershed development, environmental services, and poverty alleviation in India. World Development 30 (8):1387-1400. http://dx.doi.org/10.1016/S0305-750X(02)00042-6

Kerr, J. 2007. Watershed management: lessons from common property theory. International Journal of the Commons 1 (1):89-110. http://dx.doi.org/10.18352/ijc.8

Kerr, J., G. Milne, V. Chhotray, P. Baumann, A. J. James. 2007. Managing watershed externalities in India: theory and practice. Environment, Development and Sustainability 9:263-281. http:// dx.doi.org/10.1007/s10668-005-9022-3

Kerr, J., M. Vardhan, and R. Jindal. 2014. Incentives, conditionality and collective action in payment for environmental services. International Journal of the Commons 8:595-616. http:// dx.doi.org/10.18352/ijc. 438

Kolinjivadi, V., J. Adamowski, and N. Kosoy. 2014. Recasting payments for ecosystem services (PES) in water resource management: a novel institutional approach. Ecosystem Services 10:144-154. http://dx.doi.org/10.1016/j.ecoser.2014.08.008

Kolinjivadi, V., A. Grant, J. Adamowski, and N. Kosoy. 2015. Juggling multiple dimensions in a complex socio-ecosystem: the issue of targeting in payments for ecosystem services. Geoforum 58(1):1-13. http://dx.doi.org/10.1016/j.geoforum.2014.10.004

Kosoy, N., M. Martinez-Tuna, R. Muradian, and J. MartinezAliera. 2007. Payments for environmental services in watersheds: insights from a comparative study of three cases in Central America. Ecological Economics 61(2-3):446-455. http://dx.doi. org/10.1016/j.ecolecon.2006.03.016

Martinez, R., K. M. Green, and A. DeWan. 2013. Establishing reciprocal agreements for water and biodiversity conservation through a social marketing campaign in Quanda Watershed, Peru. Conservation Evidence 10:42-47.

McElwee, P. D. 2012. Payments for environmental services as neoliberal market-based forest conservation in Vietnam: panacea or problem? Geoforum 43(3):412-426. http://dx.doi.org/10.1016/ j.geoforum.2011.04.010 
Meinzen-Dick, R. 2007. Beyond panaceas in water institutions. Proceedings of the National Academy of Sciences of the United States of America 104(39):15200-15205. http://dx.doi.org/10.1073/ pnas.0702296104

Muradian, R., M. Arsel, L. Pellegrini, F. Adaman, B. Aguilar, B. Agarwal, E. Corbera, D. Ezzine de Blas, J. Farley, G. Froger, et al. 2013. Payments for ecosystem services and the fatal attraction of win-win solutions. Conservation Letters 6(4):274-279. http:// dx.doi.org/10.1111/j.1755-263x.2012.00309.x

Nayak, P. K., and F. Berkes. 2008. Politics of co-optation: community forest management versus joint forest management in Orissa, India. Environmental Management 41:707-718. http:// dx.doi.org/10.1007/s00267-008-9088-4

Pagiola, S., A. Arcenas, and G. Platais. 2005. Can payments for environmental services help reduce poverty? An exploration of the issues and the evidence to date from Latin America. World Development 33(2):237-253. http://dx.doi.org/10.1016/j. worlddev.2004.07.011

Pascual, U., J. Phelps, E. Garmendia, K. Brown, E. Corbera, A. Martin, E. Gomez-Baggethun, and R. Muradian. 2014. Social equity matters in payments for ecosystem services. BioScience 64 (11):1027-1036. http://dx.doi.org/10.1093/biosci/biu146

Porras, I., M. Grieg-Gran, and N. Neves. 2008. All that glitters: a review of payments for watershed services in developing countries. Natural Resource Issues No. 11. International Institute for Environment and Development, London, UK.

Poteete, A. R., and J. C. Ribot. 2011. Repertoires of domination: decentralization as process in Botswana and Senegal. World Development 39(3):439-449. http://dx.doi.org/10.1016/j. worlddev.2010.09.013

Ribot, J. C. 2009. Authority over forests: empowerment and subordination in Senegal's democratic decentralisation. Development and Change 40(1):105-129. http://dx.doi.org/10.1111/ j.1467-7660.2009.01507.x

Saberwal, V. K. 1999. Pastoral politics: shepherds, bureaucrats, and conservation in the Western Himalaya. Oxford University Press, Oxford, UK.

van Noordwijk, M., G. Galudra, B. Leimona, and G. B. Villamor. 2008. Dealing with myth perceptions: how to reduce communication and perception gaps before rewards for environmental services negotiations can start? RUPES Synthesis Notes No. 1. The World Agroforestry Centre, South East Asia Regional Office, Bogor, Indonesia.

Vira, B., W. A. Adams, C. Agarwal, S. Badiger, R. A. Hope, J. K. Swamy, and C. Kumar. 2012. Negotiating trade-offs: choices about ecosystem services for poverty alleviation. Economic \& Political Weekly XLVII(9):67-74.

Wunder, S. 2005. Payment for environmental services: some nuts and bolts. Center for International Forestry Research (CIFOR) Occasional Paper, No. 42. Bogor, Indonesia.

Wunder, S. 2013. When payments for environmental services will work for conservation. Conservation Letters 6(4):230-237. http:// dx.doi.org/10.1111/conl.12034
Wunder, S., S. Engel, and S. Pagiola. 2008. Taking stock: a comparative analysis of payments for environmental services programs in developed and developing countries. Ecological Economics 65(4):834-852. http://dx.doi.org/10.1016/j.ecolecon.2008.03.010 